\title{
The economic crisis as a game changer? Exploring the role of social construction in sustainability transitions
}

\author{
$\underline{\text { Derk Loorbach }}^{1}, \underline{\text { Flor Avelino }}^{1}, \underline{\text { Alex Haxeltine }}^{2}, \underline{\text { Julia M. Wittmaver }}^{1}$, Tim O'Riordan $^{2}$, Paul Weaver $^{3,4}$ and René Kemp $^{3,5}$
}

\begin{abstract}
Continuing economic turbulence has fuelled debates about social and political reform as much as it has stimulated actions and initiatives aimed at a more fundamental transition of dominant economic systems. This paper takes a transition perspective to explore, from a Western European viewpoint, how the economic crisis is actually viewed through a variety of interpretations and responded to through a range of practices. We argue that framing societal phenomena such as the economic crisis as "symptoms of transition" through alternative narratives and actions can give rise to the potential for (seemingly) short-term pressures to become game changers. Game changers are then defined as the combination of: specific events, the subsequent or parallel framing of events in systemic terms by engaged societal actors, and (eventually) the emergence of (diverse) alternative narratives and practices (in response to the systemic framing of events). Game changers, when understood in these terms, help to orient, legitimize, guide, and accelerate deep changes in society. We conclude that such dynamics in which game changers gain momentum might also come to play a critical role in transitions. Therefore, we argue for developing a better understanding of and methodologies to further study the coevolutionary dynamics associated with game changers, as well as exploring the implications for governance.
\end{abstract}

Key Words: economic crisis; game changers; narratives of change; practices of change

\section{INTRODUCTION}

The continuing economic crisis has spurred debates about the inadequacies of our current financial and economic systems (Loorbach and Lijnis-Huffenereuter 2013). It has drawn fresh attention to alternative economic narratives and arguably has generated an acceleration of social innovations (Haxeltine et al. 2013). In the years following the start of the recession, concern over the various repercussions on social values has waned, but concerns expressed by countermovements such as Occupy live on and are combined with other frustrations about inequality and feelings of losing out, anxieties over tax evasion by the wealthy few and multinational companies, the social and environmental damage caused by production systems, the social and budgetary costs of an aging population, and the poor employment prospects of the emerging labor force.

Meanwhile, many political and public debates seem to be primarily concerned with standard, relatively short-term, economic issues, such as monetary losses, stop-and-start economic growth, increasing unemployment, falling real estate prices, failing banks, virtually bankrupt nations, and how to get back on course to economic growth. The standard responses when national governments are struggling to get their economies healthy again are mostly about inducing more money, austerity measures, and introducing financial regulations, all often part of a broader financial-economic logic (Stiglitz 2010). The dominant focus on fighting economic deficits and problems at the expense of investing in social and ecological deficits - thereby failing to address persistent problems in these areas - can be argued to be a short-term strategy to prop up an inherently unmanageable system. Examples are the support of system banks with public money and the green growth strategy (OECD 2009, 2013a). Transition theory (Grin et al. 2010, Markard et al. 2012) suggests that such short-term fixes are typical regime-based strategies to sustain existing structures, cultures, and practices, and to fend off the threats of more radical systemic change.
The transition perspective suggests that most regular policy and governance strategies essentially reproduce existing systems and, by definition, do not address the root causes of problems that are embedded in the same structures and cultures that determine how solutions are framed and implemented. Such path-dependent development optimizing existing institutional structures will inevitably lead to recurring crises and ultimately a more disruptive, shock-wise structural change of an incumbent regime. Transition studies thus argue that solutions that address symptoms rather than the underlying structural causes tend to reinforce a lock-in and result in further emergent problems (Rotmans and Loorbach 2010, Schuitmaker 2012). We argue that the underlying causes and mechanisms of the economic crises have not been thoroughly analyzed, let alone addressed through effective policies. In a globalized economy, fundamental changes will not likely come from actions by (national) governments or incumbent businesses, as these are inherently intertwined with and dependent upon the currently still dominant financialeconomic systems and their governance. The need for alternative economic approaches, discourses, and systems is increasingly emphasized (Schor 2010, Simms 2013, Jackson 2013, van den Bergh 2013, Schor and Thompson, 2014). Even though the benefits of liberalization are still significant, it seems that the transfer of control from government to markets has substantially diminished possibilities for top-down policy making, adding to brittleness, complexity, and lock-in (Loorbach and LijnisHuffenreuter 2013).

In this paper, we take a transition perspective on transformative social innovation to conceptualize and map the systemic dynamics that have caused the economic crisis, as well as how it influences the dynamics of social transformation. We explore how the economic crisis might be considered as a phase in a broader economic transition and which types of changes coincide to develop into this direction. We thus view the economic crisis not as a phenomenon in isolation within a relatively short time frame, but as an intrinsic part, or perhaps a symptom, of deeper

${ }^{1}$ DRIFT, Erasmus University, Rotterdam, ${ }^{2}$ School of Environmental Sciences, University of East Anglia, UK, ${ }^{3}$ ICIS, Maastricht University, NL, ${ }^{4}$ LUCSUS, Lund University, Sweden, ${ }^{5}$ UNU-MERIT 
underlying structural societal changes over the longer term. The question we seek to address is how the economic crisis interacts with broader societal changes as well as which dynamics might accelerate or hamper more structural (sustainability) transitions. To this end, we ask when and how a macrolevel or landscape development like the economic crisis fundamentally changes the dominant logic, rules, and conditions of incumbent regimes. In other words, when does a macrodevelopment become a game changer (cf. Avelino et al. 2014)?

The paper builds upon theoretical work from the European FP7 project TRANSIT, which draws on transition theory to develop an empirically grounded theory on transformative social innovation. In this paper, we introduce the analytical perspective that we developed on transformative social innovation and two empirical examples. Although our analytical perspective suggests that alternatives and breakthroughs can come from any sector or actor, in this paper, we focus on the agency of social innovation and civil-society-led initiatives in providing and producing alternatives. The paper was developed through a number of iterations, workshops, and theoretical synthesizing. To develop our arguments, we build upon insights from sustainability transitions literature (Grin et al. 2010, Markard et al. 2012), social innovation research (Mulgan 2006, Murray et al. 2010, Franz et al. 2012, Westley 2013, Moulaert et al. 2013) and other fields aiming to understand the economic crisis. In addition, we include two empirical cases, transnational networks of social innovation, time banks, and the transition movement. For both cases, we draw upon a general literature review.

The paper is structured as follows. In the next section, "Economic change or transition?," we introduce the economic crisis as a multifarious phenomenon, how we understand it from a transition perspective, and how it is understood from an economist's point of view. We illustrate that it is an ambiguous phenomenon that is simultaneously seen as part of regular changes in that it is part of disruptive or transformative change. In the section "Making sense of the economic crisis?," we present a number of alternative perspectives on the economic crisis that put forward particular fundamental and systemic causes of the economic crisis and how these are translated in so called "narratives of change." In "Transformative social innovations," we highlight two specific social innovation initiatives, time banks and transition towns, which have an evident transformative claim and potential, and reflect upon how such transformative social innovations relate (themselves) to the economic crisis. In "Reconceptualizing societal transformations and the role of the economic crisis," we synthesize our findings and argue that the concepts of game changers and narratives could help to unpack the landscape and better understand how macro- and microlevels interact to trigger transformative changes at the mesolevel. In conclusion, we address the need for a better understanding of the transformative impacts of the different shades of change (in coevolution) vis-é-vis the restorative dynamics associated with incumbent regimes.

\section{ECONOMIC CHANGE OR TRANSITION?}

The economic crisis has an empirical basis in factual events and economic statistics, but is also a social construct. In a narrow sense, the term economic crisis refers to the worldwide recession of 2007-2008, which changed economic circumstances and investors' outlooks and caused governments to nationalize and/ or invest in failing banks and to stimulate the economy inter alia through bail outs, expansion of the money supply (quantitative easing), and low interest rates. It changed the lives of many whose employment or work conditions were drastically affected (Melike 2014). It also made many observers much more critical about capitalism and the stability of markets, especially financial markets (Murphy 2011, Stephan and Weaver 2011, Rifkin 2014, Weaver 2014). In Europe, the economic crisis was accompanied by (perceptions of) a debt crisis, a banking crisis, and a euro crisis, all interrelated. The financial crisis, debt crisis, bank crisis, neoliberal crisis, and global financial collapse are not just different names but also refer to different, albeit closely related, empirical phenomena. Importantly, the perception and representation of such phenomena in crisis terms can give scope for motivating and/ or justifying responses.

This economic crisis has led to measures and dynamics with profound impacts on society. Impacts that hardly could have been predicted or anticipated proactively in an objective and neutral way. As most of the formal and institutional measures originate from either governmental or financial institutes, it is to be expected that these favor nondisruptive and reinforcing measures that shift the cost of recovery toward society and strengthen even more the potential for financial-economic growth. The resulting austerity measures and state budget cuts put pressure on public sector employment, transfer payments, and social welfare systems, contributing to rising unemployment and underemployment among young and old, and lower disposable incomes for many in society. The state investments in the recovery of the banking system as well as budget cuts in welfare, health care, and education have been put forward as necessary to restabilize the economy and return to economic growth as before. Although the economy now seems on a path to recovery, many of the social and ecological tensions and challenges still persist.

From a countermovement perspective, the dominant measures have mainly strengthened incumbent regimes and even made more apparent the need for structural change. This becomes apparent by a growing dissatisfaction with capitalism, a lack of trust in financial institutions, and an increasing pressure on democratic political institutions (Castells 2010, Murphy 2011, Rifkin 2014, Weaver 2014). These in turn focus attention on the meaning and quality of life, which can intensify individuals' desires to live in a more responsible and meaningful way as citizens, workers, and consumers, which again are accompanied by an increasing attention to social value creation (based on the attention to these issues in magazines and business literature) (see O'Riordan 2013).

Over 70 years ago, Polanyi (1944) described countermovements as critical responses to the rise of liberal market economies in the interwar period. Polanyi argued that countermovements tend to include both progressive and regressive forces, and he related the rise of fascism as part of a double countermovement in reaction to the rise of liberal market economy (Worth 2013). Similarly, contemporary counternarratives do not only include progressive sustainability-oriented ideas, but also more regressive ideas as manifested in populist and/or extremist political parties. Moreover, counternarratives and grassroots movements are also not always easily discernible from mainstream discourses. Although discourses on, e.g., solidarity economy can be 
constructed as counternarratives, they have considerable overlaps with mainstream policy discourses on the "Big Society" (UK) and "the participation society" (The Netherlands). When comparing discourses on the circular economy and the sharing economy, one can find differences in the former being partly associated with a corporate movement (see, e.g., McKinsey and the Ellen McArthur Foundation) the latter being more associated with grassroots social movements (e.g., Peerby). Different discourses are intermingled, changing over time, forming double movements (Polanyi 1944), or rather multilayered narratives of change.

We use here narratives of change as an accessible and short summary of discourses on change and innovation (Avelino et al. 2014). Social (counter)movements, such as the environmental movement or the antiglobalization movement, can be experienced as counternarratives of change. These social movements "struggle against pre-existing cultural and institutional narratives and the structures of meaning and power they convey" (Davies 2002:25). They achieve this partly through counternarratives, which "modify existing beliefs and symbols and their resonance comes from their appeal to values and expectations that people already hold" (Davies 2002:25). This challenges us to expand beyond the hegemonic mainstream narrative on, e.g., the economic crisis, by including a discussion of counternarratives around the new economy.

Thus, we see a double device of addressing the economic crisis through measures to prevent the breakdown and restabilization of the existing system, and the rise of counternarratives and movements that find legitimacy in exactly these processes and measures. From antiglobalization or Occupy movements, we can discern a loss of trust in the dominant economic model of the growth society and its associated livelihood model where most material needs are satisfied through impersonal market exchange. The formalized and impersonal market exchange is questioned, resulting in concepts such as sharing, reciprocity, generalized exchange, or restricted exchange (see Befu 1977, Peebles 2010 for an overview). Although the mainstream discourse is still about how to regain adequate rates of economic growth, an underlying longer-sighted discourse (i.e., counternarrative) is emerging about alternatives for this growth model. This includes (longstanding and more recent) ideas on degrowth (Schumacher 1973, Fournier 2008), green growth (OECD 2009, 2013a), or postgrowth (Jackson 2009). These (counter)narratives also question the market logic that constructs human beings as well as nature as resources and commodities in the production of goods (Freudenburg et al. 1995).

Contemporary discourses on a new economy include calls to replace, complement, or transform the mainstream economic system with alternative paradigms. These include a wide variety of notions, e.g., social economy, informal economy, solidary economy, sharing economy, the cooperative movement, the commons, green economy, blue economy, circular economy, and so on (e.g., Rifkin 2014). Many of these narratives and associated ideas are not necessarily new as such. Indeed, many have existed for decades (or even centuries), but the game-changing economic crisis has triggered new and revitalized interest in these narratives, thereby translating relatively old narratives into a modern narrative on the new, social economy as a forward-looking response to contemporary challenges (Rifkin 2014).

\section{MAKING SENSE OF THE ECONOMIC CRISIS?}

From an economic perspective, both academically as well as empirically, there appears to be a dialectic between a dominant economic logic and countermovements-for alternative (more ecological, liberating) development, leading to a variety of narratives of change. These narratives, however, mainly focus on quite general and fundamental principles for an alternative economy but do not necessarily deepen our understanding of the potential for transformative change and how this could be achieved. In this section, we explore five critical perspectives on the economic crises and patterns of economic development that have surfaced as relevant over the past years, but have been in development for much longer. From a transition perspective, these reflect different perspectives on the root causes and dynamics that arguably require and lead to systemic changes. We broaden the dominant focus on a sociotechnical perspective on transitions and include: (1) socioeconomic, (2) socioecological, (3) sociotechnical, (4) sociopolitical and (5) sociocultural perspectives.

The first perspective is the critical socioeconomic perspective, looking at poverty, exclusion, poor skills, and (youth) unemployment. The Economist (2013:59-61) estimated there could be as many as 500 million unemployed young people in the world. Eurostat (2015) reported that unemployment in the Eurozone declined from $12 \%$ in February 2013 to $11.3 \%$ in March 2015. Youth unemployment throughout the EU rose to $24.4 \%$ in November 2012 but declined to $20.9 \%$ in March 2015. Overall, some 4.8 million young people are unemployed in the EU at present. This is a drop of some 750,000 since 2012. But there is still a genuine anxiety that millions of young adults could become a lost generation. A report by the International Federation of Red Cross and Red Crescent Societies (2013) painted a somber picture of increased poverty, of a new impoverished middle class, of losing hope, and of despair, particularly in the southern member states. The Federation warns of a deepening social crisis of poverty, xenophobia, discrimination, social exclusion, violence, and abuse. In England, young people were found to fall behind the rest of Europe in the basic skills of literary, numeracy, and computer-based problem solving (OECD 2013b). Scholars have argued that this circumstance offers the prospect of a deepening skills shortage, throttling growth, whilst creating in its wake an unemployable underclass, and that this widening inequality breeds the antithesis of any successful transition to sustainability (O'Riordan 2013). It is important to record that, although overall unemployment rates are falling, young people are either deskilling to get jobs or emigrating. One aspect of transition policy is the resurgent interest in skills-training apprenticeships and selfemployment through enterprise

Socioecological perspectives link the economic crisis to a concern that it may not be possible to recover growth sufficient for widening global prosperity without crossing planetary ecological boundaries, some of which may have already been crossed (Rockström et al. 2009). Relentless population growth and other demographic changes combined with increasing claims of the human population on natural resources and ecosystem services, create concerns over the rate at which ecological boundaries are being approached. Scholars argue that the ecological transition has already "reached the tipping point phase" (Rockstrom et al. 2009, Schellnhuber 2009). Holzman (2012) argues that every year we lose 3-5 trillion dollars in natural capital, an amount greater 
than the yearly monetary costs of the global economic crisis. The socioecological perspective thereby frames the economic crisis as a symptom of the underlying ecological debt as a result of an economic system based on growth in a world without ecological limits. At present, transitions experience suggests that little is being attended to in formal budget making. The one body with a serious remit here is the UK Natural Capital Committee (NCC). In its third report (NCC 2015), the Committee calls for a national ecological accounting process with special reference to bringing in business accounting. But this is a long way off from real action, as this general area has research momentum but very little policy of financial momentum.

From a sociotechnical perspective, Perez (2013) argues that economic crises are recurring phenomena that often overlap with technological revolutions, and that the recent economic crisis was fuelled by the internet bubble created by financial innovations in and with information and communications technology (ICT). Geels (2013) contends that the economic crisis has a negative impact on sociotechnical transitions, as austerity policies reduce public spending on, e.g., renewable energy technology. At the same time, the economic crisis opens up opportunities for green growth and a Green Industrial Revolution (Geels 2013). Perez (2013) argues that "the golden age of each technological revolution has come precisely after the major bubble bust and the subsequent recessions, which is where we are now," and that "the technological transformation that occurred during the past few decades has already provided the means for unleashing a sustainable golden age" (Perez 2013:20-22). The economic crisis is thus framed as the symptom of an underlying deeper change in sociotechnical paradigms and systems: the late phase of industrialization according to modernistic principles of central control, efficiency, and growth that might give way to the newly emerging paradigm of networked self-organizing and decentralized systems.

When perceived from a sociopolitical perspective, it can be argued that the economic crisis has created political anger over the accumulations of wealth in the hands of powerful political and financial elites. Wilkinson and Pickett (2009) and Dorling (2014) argue that inequality breeds a sense of individualism, excessive and environmentally uncaring consumption, and antagonism to the qualities of democracy. Increasing inequality could give rise to social tensions and a resistance and even hostility toward sustainability unless the explanation of sustainability is geared to the improvement of equality. It can also be postulated that the economic crisis has aggravated a significant downfall in public confidence in the European Union in many of the traditional institutions that have underpinned political, economic, and social arrangements during the $20^{\text {th }}$ century (Murphy 2011, Weaver 2014). A sociopolitical perspective thus frames the economic crisis as a symptom of socioeconomic and political struggles. The recent debates around growing inequalities illuminated by Piketty (2014) highlight the interpretation of the economic crisis as a moral crisis and the need to address power structures as well as to revisit basic conditions of a social economy.

From a sociocultural perspective, the economic crisis relates to the way in which the dominant economic model has impacted on senses of identity and feelings of attachment to place and belonging to a collective (Yuval-Davis 2006). Changes in our feelings of belonging have been traced through history.
Industrialization, migration, or urbanization lead to what Marx refers to as alienation and are at the origin of the classic distinction between "Gemeinschaft" and "Gesellschaft" (Tönnies 1940). Such a sociocultural perspective can also be extended to the perceived loss of the sacred, relating to existential needs of human beings "driven not by material need but by an inner compulsion to understand the world as a meaningful cosmos and to take up a position toward it" (Weber 1963:116-117). These sociocultural perspectives on (crisis-struck) economic development express a feeling of loss, while at the same time also creating an opening for potentially new ways of thinking and doing. This tension can be associated more fundamentally with a materialist worldview that has characterized modernity (and so-called postmodernity) and that has historically arisen in close association with the technological and social transformations of the industrial revolution (Loorbach 2014). From this perspective, the economic crisis can be perceived as being related to a deeper systemic crisis in the culture and worldview of western societies.

So, whereas the economic crisis has a clear factual and qualitative character, it is interpreted in very different ways ranging from something temporary to proving the inherent undesirability of our dominant pathway of economic development. A common characteristic in the above-mentioned perspectives is that they all frame the economic crisis as a symptom of an underlying deeper societal transformation. Combined, these perspectives suggest a quite fundamental persistent problem that is not only causing economic, social, and cultural conflicts and tensions but also drawing upon resources and capital in an unsustainable way. These perspectives argue for more fundamental changes and in various ways use the economic crisis to support previously existing arguments for deeper-lying more fundamental changes in society and the economy because of ecological, sociopolitical, cultural, or technological reasons.

\section{TRANSFORMATIVE SOCIAL INNOVATIONS}

An interesting issue in connection to the economic crisis is transformative social innovation. We conceptualize social innovation as a "(new) combination of (new) social practices and/ or social relations, incl. (new) ideas, models, rules, services and/ or products" (Avelino et al. 2014). This conceptualization builds on a number of state-of-the-art understandings of social innovation, of which there are several. Franz et al. (2012:4) argue that the "decisive characteristic of social innovation" lies in the "fact that people do things differently due to this innovation, alone or together. What changes with social innovation is social practice, the way how people decide, act and behave, alone or together" (Franz et al. 2012:5). Howaldt and Kopp (2012:47) define social innovation as "a new combination and/or new configuration of social practices in certain areas of action or social contexts." Moulaert et al. (2013:2) define social innovation more in terms of "innovation in social relations (...) not just particular actions but also (...) outcome of actions which lead to improvements in social relations, structures of governance, greater collective empowerment, and so on." Franz et al. (2012) also argue that the idea of social innovation as social practices also includes changing roles, relations, norms, and values (Franz et al. 2012; cf. Hochgerner 2012).

Social entrepreneurs, organizations, and networks across the world are working on a wide range of such social innovations, 
often through very context-specific and bottom-up initiatives. These are now experiencing a new boost in response to the economic crisis and to the emergence of narratives around a new economy. A wide range of transformative alternatives emerges, often related to specific guiding transformative visions: circular design, sharing concepts, complementary economies, value-based indicators, and alternative banking schemes. Many such alternatives have been developing for much longer, but have come back into the center of attention since the beginning of the economic crisis. In this section, we focus on two specific social innovations with transformative potential that have experienced accelerating levels of interest and activity since the beginning of the economic crisis: (1) time banking and (2) transition towns initiatives.

\section{Time banks}

Time banking is a highly versatile values-based mechanism for reciprocal service exchange. In time banking, the value of all services is equal. The unit of exchange and account is simply the hours spent giving or receiving services. The originator of time banking, Teruko Mizushima, advanced time banking as a response to failures she saw in the money system, government, and the market economy. Her initial idea was for people to make more effective use of time by enabling them to give and receive help at different stages in the life course. Starting from this point, she conceptualized time more generally as a complement to money as a medium of exchange.

From its origin, there has been a transformative intent in time banking. Mizushima's development of the idea was based on lived experience of political and economic collapse and hyperinflation in postwar Japan. Miller (2008) argues that "Mizushima's firsthand experience of the impact of spiralling and unpredictable prices on people's access to the basic necessities led her to believe that money could not be relied on as a guarantee for a secure life... and that... time savings could provide a more reliable system." Lebra (1980:138-139) notes that the concept also contains "a potential to reverse established value priorities by placing a higher value on domestic labour than had previously existed in Japan, calling into question whether paid male work really was of more worth than women's unpaid housework, which was concerned directly with human life."

In the United States, the first time bank was established by the Grace Hill Settlement in St. Louis, Missouri, stimulated by the call to action from the US War on Poverty. Although developed independently from the Japanese time banks, the core values of the Grace Hill service exchange were essentially identical to those set out by Mizushima. The potential to generalize the service exchange concept was seen by Edgar Cahn. He further theorized time banking and popularized it, founding TBUSA as a membership organization for time banks both in the USA and around the world. Cahn has been influential in drawing attention to the different economies (formal and informal) that contribute to delivering wellbeing in complementary ways and to the potential for the formal economy inadvertently to damage the informal economy, for example by disturbing the work-life balance, or by exclusion.

From these roots, time banking has spread to all continents. Time banks now exist in at least 34 countries. Time banks are especially well represented in the UK and Spain, each of which has around
300 time banks. The locations, worldwide, of local time banks belonging to two of the main transnational networking organizations, TBUSA and hOurworld, are mapped on the hOurworld website (https://www.hourworld.org). This also gives real-time information on membership- and activity levels of hOurworld members.

Time banking and the economic crisis are related because time banks are able to provide for many individual and community needs to be met without recourse to money, markets, or state welfare arrangements. Through the exchange mechanism, time banks also build social relationships and networks that strengthen communities and they provide individuals with opportunities to work, develop, and achieve recognition and reward for contributions made. As time banks are largely independent of mainstream systems, they are less vulnerable to volatility in these, such as price inflation, financial crisis, recession, or austerity. This gives time banking potential to be a dependable complementary source of economic and social wellbeing and security.

In terms of its transformative potential, time banking has at times been framed both in the USA and the UK as a response to recession, unemployment, and exclusion from paid work. In Spain, it is currently framed as a response to austerity. In Spain and the UK, it is advanced as a means to promote a more inclusive society. In the UK, it is framed also as a response to the skills gap and to the failures and retreat of the welfare state. It is tied into discussions about the aging society, to the need to rescue the health service, and to the need more generally to provide a preventative infrastructure in areas such as mental and physical health, education, crime prevention, and employability. Across our studied cases, time banking is presented as a cornerstone in creating a parallel sharing economy.

\section{Transition town/transition movement}

Another pertinent example of social innovation can be found among the many local initiatives and networks joined in the transition towns movement (Seyfang and Haxeltine 2012). The citizen-led movement was launched in September 2006 in the town of Totnes in Devon, UK by Rob Hopkins and Naresh Giangrande to address peak oil, climate change, and the global economic crisis. It is made up by place-based Transition Initiatives in which local actors collaborate and organize various projects at the community level. Since its launch in Totnes, the model has spread across the UK and internationally, counting 1120 initiatives in 43 different countries in April 2014 (Longhurst and Pataki 2015). These initiatives empower citizens to build community resilience and pioneer alternative economic and social solutions. This includes the (re)discovery of (new combinations of old and new skills and services to increase socioeconomic independence (e.g., permaculture design principles for urban farming and local food production). Several transition towns initiatives have also initiated and experimented with time banks and other complementary currencies (Seyfang and Longhurst 2013), illustrating how different social innovations can spur and empower one another. Interestingly, the concept of transition towns was initially formulated as a response to the game changers of peak oil and climate change, focusing on a guiding metaphor of energy descent (drastic reductions in levels of energy use) to prepare communities for a future where fossil-based energy would be absent or prohibitively expensive. 
After the economic crisis of 2008 , the movement was, to a significant extent, reframed as a response to austerity and possible further financial and currency crises. It thus provides an illustration of how such an initiative can adapt its narrative in the face of new game changers (Longhurst 2013). Thus, whereas transition towns can be correctly interpreted as a social innovation network that facilitates and empowers responses to the game changer of the economic crisis, it can also be understood as the latest manifestation or wave in a long tradition of anticapitalist initiatives that can be historically associated with particular persons, places, and portrayals (narratives and discourses).

The conditions for success of such movements beg further analysis, but they appear to relate to leadership, cohesive networks, progressive success, support from local government and community organizations, and an underlying sense of frustration with the old order. Should the circumstances of the economic dilemma shift even more into austerity and economic grittiness, then it is likely that transformative social innovation will flourish in many manifestations. The key will lie in moves to increase the financial autonomy of local governments and in the leadership qualities of motivated community-based actors.

\section{RECONCEPTUALIZING SOCIETAL TRANSFORMATIONS AND THE ROLE OF THE ECONOMIC CRISIS}

In this paper, we took a transition perspective to explore how the economic crisis might be understood in a broader societal context and what its implications might be. We showed how the economic crisis, having a clear factual basis, is also taken up through different perspectives in narratives about more fundamental changes (that are deemed necessary). Arguably, the economic crisis is mobilized through different discourses to create space for more disruptive changes. We also described two empirical examples of social innovations as part of a wide diversity of cases that clearly respond to the economic crisis and seek to put forward alternatives. Arguably such social innovations mobilize the economic crisis to legitimize the solutions they put forward and increase their visibility and added value. Our argument is therefore that the economic crisis is both helping to give rise to and to strengthen counternarratives or discourses, in that it helps to accelerate and diffuse social innovations.

From a transition perspective, we can understand such dialectics as the coevolution between (perceived) landscape changes and emerging niches. Combined, these increase pressures on incumbent regimes that already struggle to deal with the economic crisis through optimization strategies. In this view, the current economic crisis might turn into a game changer in that it leads to a fundamental change in the dominant economic paradigm and visible concrete alternatives that will trigger structural changes at the regime level. These insights about such coevolving changes at different levels have been further conceptualized in terms of "five shades of change" (Avelino et al. 2014), but here we have mainly explored the concepts of game changers, narratives, and social innovation. Our interest lies in how qualitatively different types of change interrelate and interact. We do not presume a particular point of origin or causality, but rather see the different shades of change as a conceptual heuristic to guide our empirical and theoretical analysis of emergent deep change in society. In distinguishing between these different types of change, we focus on those processes that explicitly produce transformative alternative practices, structures, and cultures.

In this way, we deepen the concept of landscape, which plays an important role in transition studies. So far, the landscape includes all those external macrofactors that influence the dynamics within a regime. We have alternatively conceptualized the economic crisis as a phenomenon internal to the system, coevolving with societal discourses and empowering transformative social innovation. In this way, the economic crisis is an example of a game changer: a macrophenomenon that pushes a complex societal system out of its dynamic equilibrium. To be a game changer, a macrodevelopment must thus change the dominant understandings, values, institutions, and social relationships through which society is organized and defined. This is likely to be a slow and gradual process, operating through narratives of change and developments on the ground. The economic crisis is a clear example of this, yet with quite uncertain consequences for the future course of development. Our contingency view on history prevents us from making predictions.

We found, however, that the economic crises does offer scope for progressive developments, including (renewed debates about) a merging of the public, private, and civil spheres to support social innovation, opening up the possibility for all of these sectors to work together in creating/supporting social innovation based around new economic models. Under such conditions, the economic crisis in itself can be understood as accelerating the convergence of these developments and in this way becomes a game changer. However, empirical observations also suggest a more nuanced interpretation: whereas indeed the crisis has encouraged the search for alternatives, these seem still very diverse, fragmented, and small in scale to provide a full-scale solution.

Although the legitimacy of capitalism has been questioned, this has not as yet proven to be a fatal blow. As Mark Fischer (2009) famously argued, it is easier to imagine the end of the world than the end of capitalism. The same pressures (and power relations) that led to the economic crisis not being foreseen (and/or allowed to happen) may likely affect the way in which the game changer is understood and acted upon by society. Actors have developed certain (counter)narratives in response to the economic crisis. Nevertheless, the search for new and adapted models of capitalism as well as for alternative, complementary, and blended approaches to how societies meet their needs, has been boosted and given added urgency by the tensions and contradictions that the economic and financial crises have brought to the fore (Rifkin 2014, Weaver 2014).

Our perspective implies a more nuanced understanding of complex societal crises not only as temporary periods of stress in society but as symptoms and accelerators of deeper underlying processes of change. But our perspective also might have practical implications. It could, for example, imply that social innovators can increase the transformative potential of their social innovations by smartly playing into the societal game changers of their times, while simultaneously connecting to political (calls for) system innovation, as well as linking up with multilayered narratives of change in both mainstream and grassroots movements. By anticipating game changers and the inevitable tensions in perceived crises, actors can prepare for strategically 
proposing systemic alternatives when key opportunities open up (Rotmans et al. 2001, Loorbach and Lijnis-Hueffenreuter 2013). An example is social innovators smartly playing into societal game changers of their times, while simultaneously connecting to political (calls for) system innovation, as well as linking up with multilayered narratives of change in both mainstream and grassroots movements.

\section{CONCLUSION}

This paper set out to explore how we can understand the economic crisis from a transitions perspective. The persistency of problems associated with our currently dominant economic regimes (e.g., unemployment, inequality, ecological degradation) seems evident and reason for concern and action. We summarized a variety of alternative perspectives or discourses from which the argument for more fundamental systemic change is made. These debates combined with the perceived effects of the crises create space and agency for transformative social innovation. We argued that there is an increasing convergence among the transformative discourses, narratives, and practices, but also that it is impossible to foresee or predict future developments. In exploring the economic crisis this way, we also sought to unpack the concept of landscape and further develop our conceptual understanding of interacting different types of change.

From a transition perspective, we argue that the combination of such different types of changes (crises internal to the presently dominant economic system, counternarratives, and a critical mass of concrete alternative practices and models) are the ingredients for a chaotic, nonlinear, and structural period of structural systemic change (Loorbach 2014). Game changers such as the economic crisis tend to give rise to (or at least coincide with) emerging social unrest, political debates, discussions about the dismantling/redefining of the state, and debates about the (re) scaling of governance mechanisms. Social innovation initiatives, such as time banks and transition movement, often go hand in hand with narratives on (re)localization (Bailey et al. 2010) and self-governance and self-organization (Boonstra and Boelens 2011, Eriksson 2012, Meerkerk et al. 2012). A pertinent question is how these narratives on new forms of governance relate to the role(s) of governments and intergovernmental institutions such as the EU, and how (the interaction between) different types of governance responses and approaches influence the dynamics of transformative social innovation. With this paper, we hope to encourage further analysis into the economic crisis as a game changer and stimulate further work on understanding societal transitions.

Responses to this article can be read online at: http://www.ecologyandsociety.org/issues/responses. $\mathrm{php} / 8761$

\section{Acknowledgments:}

This article is based on research carried out as part of the Transformative Social Innovation Theory (TRANSIT) project, funded by the European Union's Seventh Framework Programme (FP7) under grant agreement 613169. The views expressed in this article are the sole responsibility of the authors and do not necessarily reflect the views of the European Union.

\section{LITERATURE CITED}

Avelino, F., J. M. Wittmayer, T. O'Riordan, A. Haxeltine, P. Weaver, R. Kemp, D. Loorbach, and J. Rotmans. 2014. Gamechangers and transformative social innovation. The case of the economic crisis and tranformative social innovation. TRANSIT Working Paper, TRANSIT: EU SSH.2013.3.2-1 Grant agreement no: 613169 .

Bailey, I., R. Hopkins, and G. Wilson. 2010. Some things old, some things new: the spatial representations and politics of change of the peak oil relocalisation movement. Geoforum 41:595-605. http://dx.doi.org/10.1016/j.geoforum.2009.08.007

Befu, H. 1977. Social exchange. Annual Review of Anthropology 6:255-281. http://dx.doi.org/10.1146/annurev.an.06.100177.001351

Boonstra, B., and L. Boelens. 2011. Self-organisation in urban development: towards a new perspective on spatial planning. Urban Research and Practice 4(2):99-122. http://dx.doi.org/ http://dx.doi.org/10.1080/17535069.2011.579767

Castells, M. 2010. End of millennium. Second edition. Blackwell, Oxford, UK. http://dx.doi.org/10.1002/9781444323436

Davies, J. E. 2002. Stories of change. Narrative and social movements. State University of New York Press, Albany, New York, USA.

Dorling. D. 2014. Inequality and the 1\%. Verso, London, UK.

Eriksson, K. 2012. Self-service society: participative politics and new forms of governance. Public Administration 90(3):685-698 http://dx.doi.org/10.1111/j.1467-9299.2011.01996.x

Eurostat. 2015. Unemployment statistics. [online] URL: http://ec. europa.eu/eurostat/statistics-explained/index.php/

\section{Unemployment statistics}

Fischer, M. 2009. Capitalist realism: is there no alternative? John Hunt Publishing, UK.

Fournier, V. 2008. Escaping from the economy: politics of degrowth. International Journal of Sociology and Social Policy 28 (11/12):528-545. http://dx.doi.org/10.1108/01443330810915233

Franz, H. W., J. Hochgerner, and J. Howaldt. 2012. Challenge social innovation: potentials for business, social entrepreneurship, welfare and civil society. Springer Science \& Business Media, Berlin, Germany. http://dx.doi.org/10.1007/978-3-642-32879-4

Freudenburg, W. R., S. Frickel, and R. Gramling. 1995. Beyond the nature/society divide: learning to think about a mountain. Sociological Forum 10(3):361-39.

Geels, F. W. 2013. The impact of the financial-economic crisis on sustainability transitions: financial investment, governance and public discourse. Environmental Innovation and Societal Transitions 6:67-95. http://dx.doi.org/10.1016/j.eist.2012.11.004

Grin, J., J. Rotmans, and J. Schot. 2010. Transitions to sustainable development; new directions in the study of long term transformative change. Routledge, New York, New York, USA. 
Haxeltine, A., F. Avelino, J. Wittmayer, R. Kemp, P. Weaver, J. Backhaus, and T. O'Riordan. 2013. Transformative social innovation: a sustainability transitions perspective on social innovation. Pages 1-19 in Proceedings of the NESTA Conference, Social frontiers: the next edge of social science research, 14-15 November 2013, London UK. [online] URL: http://www.scribd. com/doc/191799102/Transformative-social-innovations-A-sustainabilitytransition-perspective-on-social-innovation

Hochgerner, J. 2012. New combinations of social practices in the knowledge society. Pages 87-104 in H. W. Franz, J. Hochgerner, and J. Howaldt, editors. Challenge social innovation: potentials for business, social entrepreneurship, welfare and civil society. Springer, Berlin/Heidelberg, Germany. http://dx.doi.org/10.1007/978-3-642-32879-4 6

Holzman, D. C. 2012. Accounting for nature's benefits: the dollar value of ecosystem services. Environmental Health Perspectives 120(4):a152-a157. http://dx.doi.org/10.1289/ehp.120-a152

Howaldt, J., and R. Kopp. 2012. Shaping social innovation by social research, Pages 43-56 in H.-W. Franz, J. Hochgerner, and J. Howaldt, editors. Challenge social innovation: potentials for business, social entrepreneurship, welfare and civil society. Springer, Berlin/Heidelberg, Germany.

International Federation of Red Cross and Red Crescent Societies (IFRC). 2013. Think differently: humanitarian impacts of the economic crisis in Europe. IFRC, Geneva, Switzerland.

Jackson, T. 2009. Prosperity without growth: economics for a finite planet. Sustainable Development Commission, London, UK. http://dx.doi.org/10.4337/9781781951415.00015

Jackson, T. 2013. New economic model needed, not relentless consumer demand. The Guardian Blog. 17 January 2013. [online] URL: https://www.theguardian.com/sustainable-business/blog/ new-economic-model-not-consumer-demand-capitalism

Lebra, T. K. 1980. Autonomy through interdependence: the housewives labor bank, The Japan Interpreter 13:133-42.

Longhurst, N. 2013. The emergence of an alternative milieu: conceptualising the nature of alternative places, Environment and Planning A45:2100-2119. http://dx.doi.org/http://dx.doi.org/10.1068/ $\underline{\mathrm{a} 45487}$

Longhurst, N., and G. Pataki. 2015. The transition movementTRANSIT case study report. TRANSIT: EU SSH.2013.3.2-1 Grant agreement no: 613169.

Loorbach, D. 2014. To transition! Governance Panarchy in the New Transformation. inaugural lecture, DRIFT, Ersmus University Rotterdam, The Netherlands.

Loorbach, D., and R. Lijnis-Hueffenreuter. 2013. Exploring the economic crisis from a transition management perspective. Environmental Innovation and Societal Transitions 6:35-46. http:// dx.doi.org/10.1016/j.eist.2013.01.003

Markard, J., R. Raven, and B. Truffer. 2012. Sustainability transitions: an emerging field of research and its prospects, Research Policy 41(6):955-967. http://dx.doi.org/http://dx.doi. org/10.1016/j.respol.2012.02.013

Meerkerk, I., B. Boonstra, and J. Edelenbos. 2012. Selforganization in urban regeneration: a two-case comparative research. European Planning Studies 21(10):1630-1652. http://dx. doi.org/10.1080/09654313.2012.722963

Miller, J. 2008. Teruko Mizushima: pioneer trader in time as a currency, Intersections: gender and sexuality in Asia and the Pacific 17. [online] URL: http://intersections.anu.edu.au/issue17/miller. $\underline{\mathrm{htm}}$

Moulaert, F., D. MacCallum, A. Mehmood, and A. Hamdouch, editors. 2013. The international handbook on social innovation: collective action, social learning and transdisciplinary research. Edward Elgar Publishing, Cheltenham, UK. http://dx.doi. org/10.4337/9781849809993

Mulgan, G. 2006. The process of social innovation, Innovations, MIT Press Journals 1(2):145-162.

Murphy, J. 2011. Capitalism and transparency. Critical Perspectives on International Business 7:125-141. http://dx.doi. org/10.1108/17422041111128212

Murray, R., J. Caulier-Grice, and G. Mulgan. 2010. The open book of social innovation. The Young Foundation, NESTA, London, UK.

Natural Capital Committee (NCC). 2015. The state of natural capital. Protecting and improving natural capital for prosperity and wellbeing. NCC, London, UK. [online] URL: http://nebula. wsimg.com/272833c20f4e7f67e2799595a 7f06088?

Access KeyId=68F83A8E994328D64D3D\&disposition=0\&alloworigin=1

Organisation for Economic Co-operation and Development (OECD). 2009. Green growth: overcoming the crisis and beyond. OECD Publishing, Paris, France. http://dx.doi.org/10.1787/9789264083639-en

OECD. 2013a. Putting green growth at the heart of development. OECD Green Growth Studies, OECD Publishing, Paris, France.

OECD. 2013b. Skills outlook 2013: first results from the survey of adult skills. OECD Publishing, Paris, France.

O'Riordan, T. 2013. Sustainability for wellbeing, Environmental Innovation and Societal Transitions, 6:24-34, http://dx.doi.org/ http://dx.doi.org/10.1016/j.eist.2012.12.001

Peebles, G. 2010. The anthropology of credit and debt. Annual review of Anthropology 39:225-240. http://dx.doi.org/10.1146/ annurev-anthro-090109-133856

Perez, C. 2013. Unleashing a golden age after the financial collapse: drawing lessons from history, Environmental Innovation and Societal Transitions 6:9-23. http://dx.doi.org/http://dx.doi. org/10.1016/j.eist.2012.12.004

Piketty, T., and A. Goldhammer. 2014. Capital in the twenty-first century. Belknap Press, Cambridge, Massachusetts, USA. http:// dx.doi.org/10.4159/9780674369542

Polanyi, K. 1944. 2001. The great transformation. Beacon, Boston, Massachusetts, USA.

Rifkin, J. 2014. The zero marginal cost society: the internet of things, the collaborative commons, and the eclipse of capitalism. Palgrave Macmillan, London, UK.

Rockström, J., W. Steffen, K. Noone, A. Persson, F. Stuart Chapin, III, E. Lambin, T. M. Lenton, M. Scheffer, C. Folke, H. 
J. Schellnhuber, B. Nykvist, C. A. de Wit, T. Hughes, S. van der Leeuw, H. Rodhe, S. Sörlin, P. K. Snyder, R. Costanza, U. Svedin, M. Falkenmark, L. Karlberg, R. W. Corell, V. J. Fabry, J. Hansen, B. Walker, D. Liverman, K. Richardson, P. Crutzen, and J. Foley. 2009. Planetary boundaries: exploring the safe operating space for humanity. Ecology and Society 14(2): 32. http://dx.doi. org/10.1111/j.1540-5842.2010.01142.x

Rotmans, J., R. Kemp, and M. Asselt. 2001. More Evolution than revolution: transition management in public policy. The Journal of Futures Studies, Strategic Thinking and Policy 3(1):15-32. http://dx.doi.org/10.1108/14636680110803003

Rotmans, J., and D. Loorbach. 2010. Towards a better understanding of transitions and their governance: a systemic and reflexive approach. Part II in J. Grin, J. Rotmans, and J. Schot, editors. Transitions to sustainable development; new directions in the study of long term transformative change. Routledge, New York, New York, USA.

Schellnhuber, H. J. 2009. Tipping elements in the earth system. Proceedings of the National Academy of Sciences, 106(49), 2056120563. http://dx.doi.org/10.1073/pnas.0911106106

Schor, J.B. 2010. Plenitude; the new economics of true wealth. Penguin, New York, NY, USA.

Schor, J. B., and C. J. Thompson. 2014. Sustainable lifestyles and the quest for plenitude: case studies of the new economy. Yale University Press, New Haven, Connecticut, USA; London, UK.

Schuhmacher, E. F. 1973. Small is beautiful: a study of economics as if people mattered. Blond and Briggs, London, UK.

Schuitmaker, T.-J. 2012. Identifying and unravelling persistent problems. Technological Forecasting and Social Change 79(6): 1021-1031. http://dx.doi.org/10.1016/j.techfore.2011.11.008

Seyfang, G., and A. Haxeltine. 2012. Growing grassroots innovations: exploring the role of community-based initiatives in governing sustainable energy transitions. Environment and Planning C: Government and Policy 30:381-400. http://dx.doi. org/10.1068/c10222

Seyfang, G., and N. Longhurst. 2013. Desperately seeking niches: grassroots innovations and niche development in the community currency field. Global Environmental Change 23(5): 881-891. http://dx.doi.org/10.1016/j.gloenvcha.2013.02.007

Simms, A. 2013. Cancel the apocalypse: the new path to prosperity. Abacus, London, UK.

Stephan, H., and P. M. Weaver. 2011. Globalization, national development, and sustainable development: which pathways and interventions might lead to greater compatibility? Globalisation Informed by Sustainable Development (GLOBIS), CORDIS, European Union, Brussels, Belgium. [online] URL: http://lucsus. $\underline{\text { lu.se.webbhotell.1dc.lu.se/wp-content/uploads/2015/02/ }}$ D8D9 Synthesis report.pdf

Stiglitz, J. E. 2010. Freefall: America, free markets, and the sinking of the world economy. W.W. Norton \& Company, New York, New York, USA.

The Economist. 2013. Storm survivors: a special report on offshore finance. The Economist 17 February 2013, London, UK.
Tönnies, F. 1940. Fundamental concepts of sociology (Gemeinschaft und Gesellschaft). Translated from the German by C. P. Loomis. American Book Company, New York, New York, USA.

van den Bergh, J. C. J. M. 2013. Economic-financial crisis and sustainability transition: introduction to the special issue, Environmental Innovation and Societal Transitions 6:1-8. http:// dx.doi.org/http://dx.doi.org/10.1016/j.eist.2013.01.004

Weaver, P. M. 2014. The informal, collaborative and"zero marginalcost" economies. Policy Brief, GLOBIS Project, Brussels Workshop, May 2014, Brussels, Belgium.

Weber, M. 1963. The sociology of religion. Beacon, Boston, Massachusetts, USA.

Westley, F. 2013. The history of social innovation. Key note lecture, NESTA Conference, Social Frontiers: The Next Edge of Social Science Research, 14-15 November 2013, London, UK. [online] URL: http://www.nesta.org.uk/sites/default/files/

key note_speech_frances_westley_on the history_of_social_innovation. pdf

Wilkinson, R., and K. Pickett. 2009. The spirit level. The Equality Trust, York, UK.

Worth, O. 2013. Polanyi's magnum opus? Assessing the application of the counter-movement in international political economy. The International History Review 35(4):905-920. http:// dx.doi.org/http://dx.doi.org/10.1080/07075332.2013.817464

Wulfgramm, M. 2014. Life satisfaction effects of unemployment in Europe: the moderating influence of labour market policy. Journal of European Social Policy 24(3):258-272. http://dx.doi. org/10.1177/0958928714525817

Yuval-Davis, N. 2006. Belonging and the politics of belonging. Patterns of Prejudice 40(3):197-214. http://dx.doi.org/http://dx. doi.org/10.1080/00313220600769331 